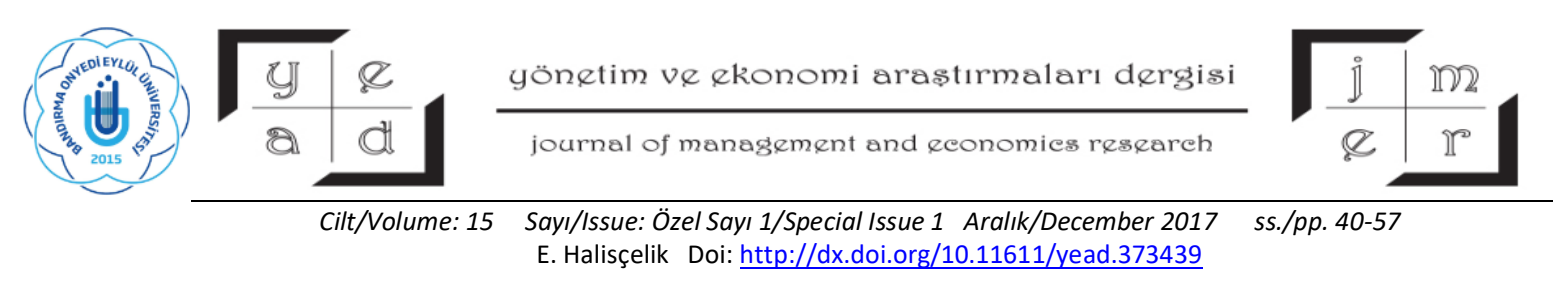

\title{
HOW TO DELIVER FREE COAL TO THE POOR FAMILIES? TURKEY CASE ${ }^{1}$
}

\section{Dr. Ergül HALİSÇELİK ${ }^{2 *}$ iD}

\begin{abstract}
Turkish government delivers free coal to poor families via General Directorate of Coal Industry (GDCI) as a part of social and economic policy. Although project has many components, generally the coal is taken from several mines within country, after basic industrial process, the coal is sent to main delivery nodes from mines nodes by highways, seaways or railroads. Finally, the poor families come to main nodes and carry the coal to their houses to use during the winter.

The cost of delivering free coal is reimbursed by Turkish Treasury to GDCI as duty loss under some government regulations. In this study, after giving general information about the problem and describing situation in Turkey, it will be developed transportation and transshipment models by taking into consideration some assumptions. The problem will be solved with alternative methods by giving useful and applicable recommendations for GDCI to reduce cost of this public policy and to enable them to help as many as poor families to have free coal in timely fashion.
\end{abstract}

Key Words: Optimization, Operations Research, Management Science, Turkey, Free Coal, Poor Families, Transportation Models, Transshipment Models

JEL Classification: C44, C54, C61, G18, H44

\section{YOKSUL AİLELERE ÜCRETSIZZ KÖMÜR NASIL DAĞITILIR? TÜRKIYE ÖRNEĞİ}

\section{ÖZ}

Türk hükümeti, sosyal ve ekonomik politikaların bir parçası olarak Türkiye Kömür İ̧sletmeleri Genel Müdürlüğü (GDCI) vasitasıyla yoksul ailelere ücretsiz kömür sağlamaktadır. Projenin birçok bileşeni olmasına rağmen, genel olarak kömür ülkedeki birkaç madenden alınmakta; temel sanayi

\footnotetext{
${ }^{1}$ The first draft of this paper is presented ICOAEF 2017 conferance on 06-07 December 2017

${ }^{2}$ Senior Treasury Controller at Republic of Turkey Prime Ministry Undersecretariat of Treasury, Vice Chairman of Mülkiye Economic and Research Center. Part-Time Lecturer at Baskent \& TED Universities.

* The views represented in this paper are those of the author and do not necessarily reflect the positions or policies of the Republic of Turkey Undersecretariat of Treasury, Ankara, Turkey, ergul.haliscelik@ hazine.gov.tr
} 
Yönetim ve Ekonomi Araștırmaları Dergisi / Journal of Management and Economics Research

Cilt/Volume: 15 Sayı/Issue: Özel Sayı 1/Special Issue 1 Aralık/December 2017 ss./pp. 40-57

E. Halisçelik Doi: http://dx.doi.org/10.11611/yead.373439

işlemlerinden sonra da karayolu, deniz ya da demiryolları ile ana dăğtım noktalarına gönderilmektedir. Projenin son aşamasında ise, yoksul aileler ana dă̆ıtım noktalarına gelerek kömürlerini almakta ve kış boyunca kullanmak için evlerine taşımaktadır.

Ücretsiz kömür dağıtma projesinin maliyeti, yapılan düzenlemeler uyarınca, Hazine Müsteşarlığı tarafindan GDCI'ye görev zararı olarak geri ödenmektedir. Bu çalışmada, proje hakkında genel bilgi verildikten ve Türkiye'deki mevcut durum ortaya konduktan sonra, bazı varsayımlarla, ulaştırma ve aktarma modelleri gelişstirilecektir. Problem alternatif yöntemlerle çözülerek, proje çervesinde uygulanacak kamu politikasının maliyetini düşürmek ve mümkün olduğu kadar çok sayıda yoksul ailenin projeden faydalanarak zamanında ücretsiz kömür ihtiyaçlarını gidermelerini sağlamak için GDCI'na faydalı ve uygulanabilir öneriler sunulacaktır.

Anahtar Kelimeler: Optimizasyon, Yöneylem Araştırması, Yönetim Bilimi, Türkiye, Ücretsiz Kömür, Yoksul Aileler, Ulaştırma Modelleri, Aktarma Modelleri

Jel Sinıflandirması: $C 44, C 54, C 61, G 18, H 44$

\section{INTRODUCTION}

Turkish government delivers free coal to poor families via General Directorate of Coal Industry (GDCI) as a part of social and economic policy. Although project has many components, generally the coal is taken from several mines within country, after basic industrial process, the coal is sent to main delivery nodes from mines nodes by highways, seaways or railroads. Finally, the poor families come to main nodes and carry the coal to their houses to use during the winter.

The cost of delivering free coal is reimbursed by Turkish Treasury to GDCI as duty loss under some government regulations. The strategic objective of the project, by providing free coal, is to help poor families to sustain harsh and cold winters. The fundamental objectives are to close the gap of life quality between poor and rich people and to reduce child sickness because of cold weather. The means objectives are to reduce imported oil consumption for heating houses and to stimulate transportation industry.

The 3E's (Economy, Efficiency and Effectiveness) objectives are to decrease the cost of delivering coal via shortest path, to produce coal in timely fashion and using best way of transportation method. Those objectives are main areas to use Operations Research and Management Science tools concerned with scientifically deciding to design and operate systems optimally by using of mathematical models 
Yönetim ve Ekonomi Arastırmaları Dergisi / Journal of Management and Economics Research

Cilt/Volume: 15 Sayı/Issue: Özel Sayı 1/Special Issue 1 Aralık/December 2017 ss./pp. 40-57

E. Halisçelik Doi: http://dx.doi.org/10.11611/yead.373439

to investigate complex problems under conditions requiring the best allocation of scarce resources (Winston and Venkataraman, 2003:1-10; Taha, 2003; Ragsdale, 2004; Johnson, 2006).

According to project of "Delivering Free Coal to Poor Families", the coal is taken from several mines within Turkey. Those mine nodes have certain amount of production capacity and they also have previously engaged supply commitment (GDCI, 2006). Therefore they will use only some part of their production capacity for this project. For example; despite the fact that the Manisa node has total capacity of 15.000 tons/year, it has 9.000 ton/year of previously engaged production capacity. Therefore Manisa mine node has just 6.000 ton/year maximum capacity devoted to this project. This operations restriction is illustrated by Figure 1.

At the very beginning of the project GDCI determines the total coal supply coming from several mines. The second stage of the project is to determine the total demand of coal. The demand is determined by the Turkish Treasury with consulting the Social Solidarity Fund (SSF), Ministry of Environmental Affairs (MOEA), Ministry of Finance (MOF), Ministry of Development, State Meteorology Institute (SMI), Ministry of Transportation (MOT), Ministry of Energy and Natural Resources (MOER), Local Municipalities (LM) and other responsible governmental agencies.

The relevant Department of the Turkish Treasury gets following information necessary to determine the needs of each demand nodes (Republic of Turkey Ministry of Transportation, 2006; Republic of Turkey Ministry of Energy and Natural Resources, 2006):

- The number of poor families from SSF and STO,

- Income level of those families from MOF and LMs,

- Pollution rate of local area MOEA,

- Weather conditions of demand node SMI,

- Transportation facility options from MOT,

- Available/alternative natural resources in demand node from MOER,

In our model, to give an insight about determining the demand in cities, we used the weather conditions, pollution rates, number of people in cities and their indexes with respect to total level these variables. After collecting these data by Turkish Treasury, it assigns the GDCI to deliver the free coal to the families in need in across the Turkey as the cost of delivery is reimbursed by the Turkish Treasury.

\section{METHOD, MODELS AND ASSUMPTIONS}

\section{1) Transportation Methods}

The all transportation methods, except airway, are generally used by the GDCI to delivery. GDCI is given the distances between all the supply nodes and demand nodes. The distances can be railroad 
Yönetim ve Ekonomi Araștırmaları Dergisi / Journal of Management and Economics Research

Cilt/Volume: 15 Sayı/Issue: Özel Sayı 1/Special Issue 1 Aralık/December 2017 ss./pp. 40-57

E. Halisçelik Doi: http://dx.doi.org/10.11611/yead.373439

$(\mathrm{km})$, seaway (mile) and highway $(\mathrm{km})$ by the MOT. Based on past experiences, GDCI also have the information about delivery ton/ $\mathrm{km}$ cost of coal. The delivery cost structure is given at the Table 1 :

Table 1: The Delivery Cost Structure

\begin{tabular}{|c|c|}
\hline Type of Transportation & Unit Cost (ton/km or mile) \\
\hline Highway & $\$ 1.00$ \\
\hline Railroad & $\$ 0.10$ \\
\hline Seaway & $\$ 0.15$ \\
\hline
\end{tabular}

Source: Republic of Turkey Ministry of Transportation \& GDCI

As seen from the Table 1 above, the unit cost for delivery with railroad is the cheapest $(\$ 0.10$ ton $/ \mathrm{km}$ ) among the others. Although there is a highway between all the supply nodes and the demand nodes, the restricted number of demand nodes has railroad and seaway transshipment nodes. In those cases, the coal is first sent to transshipment nodes by GDCI and then to final demand nodes, if the cost is cheaper than highway. We want to mention that all transshipment nodes have 0 (zero) demand and supply.

\section{2) Type of Problem}

Our project is related with network flow problem. These problems are used for a number of practical decisions in business. Based on the information above; we have determined that our model is a typical transshipment problem.

Our model is a transshipment problem. Transshipment problem deals with the distribution of goods from several points of supply to a number of points of demand (Greenberg, 2006). It may also contain transshipment points through which coal can be shipped on their way from a supply point (shipments from sources) to demand point (to destinations) so that total production and transportation costs of project of "Delivering Free Coal to Poor Families" are minimized (Winston and Venkataraman, 2003:360-406; Albright, 2001; Hillier, and Lieberman, 1995; Daskin, 1995;Johnson, 2006).

\section{3) Model and Assumptions}

GDCI has 21 supply nodes and it is generally assign to deliver the free coal to 1738 demand nodes of which are cities and townships. To simplify the solution, in our model, we will only use 6 supply nodes including Bolu, Canakkale, Corum, Kutahya, Manisa and Sirnak whereas we will use 8 demand nodes including Adana, transshipment nodes some of which are seaway and the others are 
Yönetim ve Ekonomi Araștırmaları Dergisi / Journal of Management and Economics Research

Cilt/Volume: 15 Sayı/Issue: Özel Sayı 1/Special Issue 1 Aralık/December 2017 ss./pp. 40-57

E. Halisçelik Doi: http://dx.doi.org/10.11611/yead.373439

railroad centers. Izmir, Mersin and Samsun are the transshipment nodes which seaway and highway are used while Ankara and Erzurum are the transshipment nodes that railroad and highway are used.

As it is seen in Figure 1 below, the coal can be transported just by one transportation method or as long as there are alternative transportation methods combination of two or three transportation method can be applied. For instance from sample mine to a sample node coal can be transported by highway and this route is illustrated by dashed black line with truck icon. The same transportation can be realized by either highway and truck combination or first railroad second seaway and seaway to final destination.

Figure 1 : Illustration of a Sample Transshipment Structure of the Project

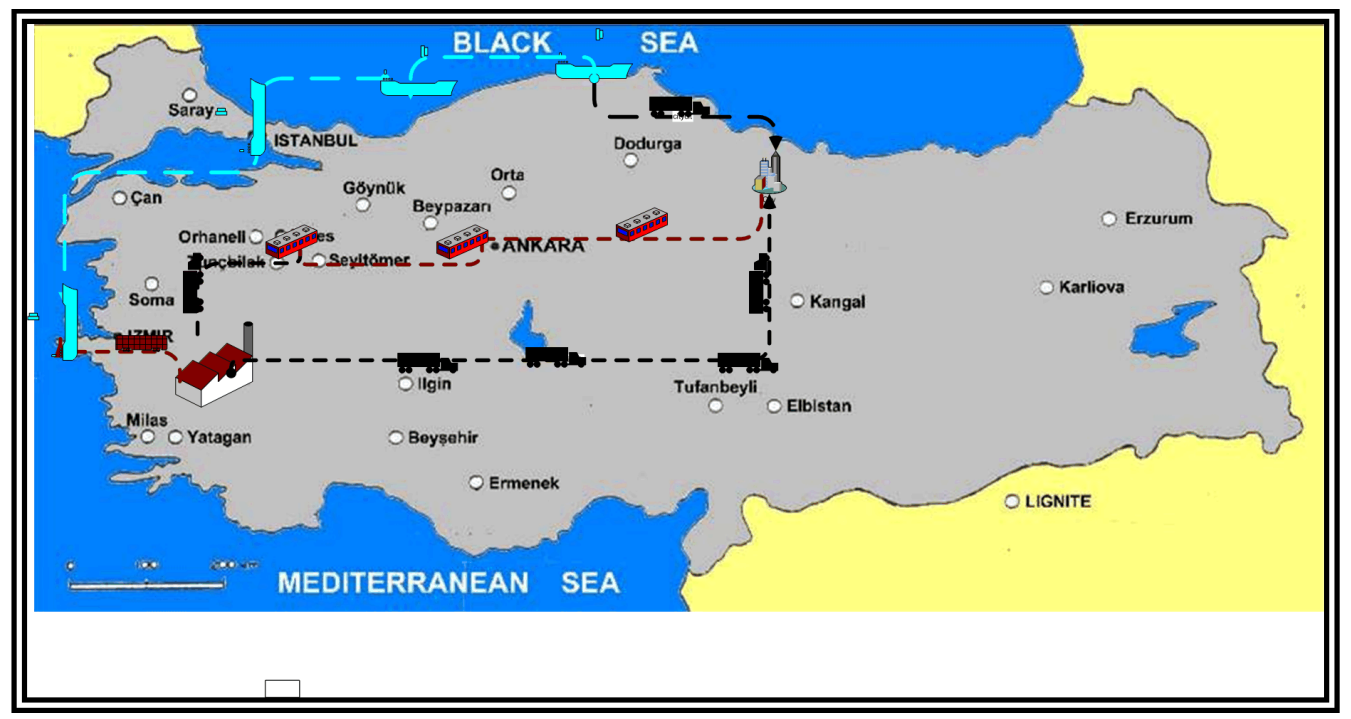

Source: Republic of Turkey Ministry of Transportation

GDCI has very complicated production process. Therefore we have to make some other assumptions (Cohon, 1978; Fourer, Gay and Kernighan, 2003; Johnson, 2006):

a- The capacity of mines are fixed and does not change because of any interruption of production,

b- Production function is linear.

c- Loading and dumping costs are ignored

d- It is assumed that shortest path between nodes are always available. The weather conditions of seaway or maintenance of railroads or other possible interruptions are ignored

\section{4) Purposes and Goals of the Project}

The project has the following objectives:

1- Minimizing the total cost of coal transportation by choosing best (cheapest) combination of transportation methods with respect to fulfilling demand on poor families in demand nodes. (Transshipment Problem) 
2- Minimizing the number of facility location that is required to cover all the coal demands for poor family in demand nodes. (Facility Location Set-Covering Problem)

\section{ALTERNATIVE SOLUTION METHODS \& RESULTS}

We think that we can solve our problem by using either Facility Location Set-Covering Problem or Transshipment Method. Despite we have decided to solve our model by using transshipment method we presented both models' objective functions' and constraints' notations.

\section{1) Facility Location Set-Covering Problem}

Decision Variable: $\mathrm{x}_{\mathrm{j}=1}$ if Transshipment node (facility) is located in city $\mathrm{j}, 0$ otherwise.

Objective function:

Minimize: $\sum_{j=1}^{7} x_{j}$

So we can write out LP formula as

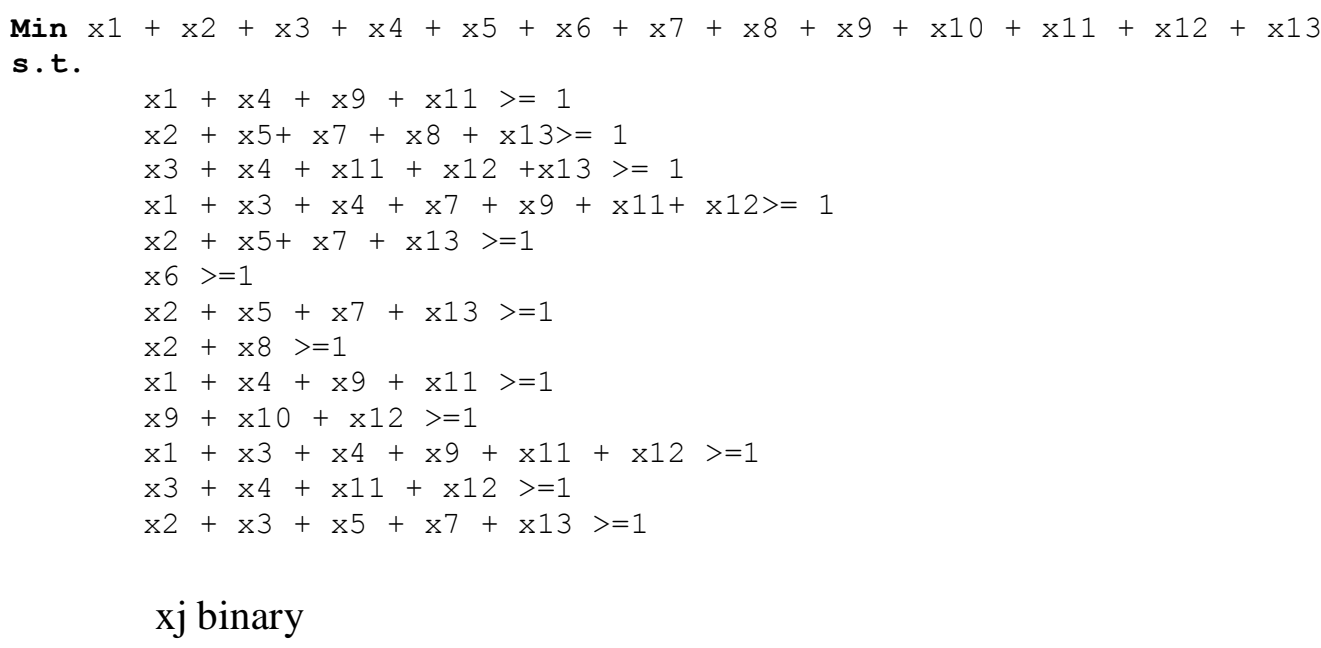

xj binary

- Build the minimal number of facility location such that at least one location is within $500 \mathrm{~km}$ of each city. (demand nodes)

- 13 cities in our model

- The distance $(\mathrm{km})$ between the cities is in the table below. 
Yönetim ve Ekonomi Araștırmaları Dergisi / Journal of Management and Economics Research

Cilt/Volume: 15 Sayı/Issue: Özel Sayı 1/Special Issue 1 Aralık/December 2017 ss./pp. 40-57

E. Halisçelik Doi: http://dx.doi.org/10.11611/yead.373439

Table 2: The Distance (km) Between the Cities

\begin{tabular}{|c|c|c|c|c|c|c|c|c|c|c|c|c|c|}
\hline CITY NAME & 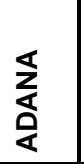 & 忞 & $\underset{\sum}{\overleftarrow{c}}$ & $\begin{array}{l}\underset{\mathbb{q}}{\mathbf{q}} \\
\frac{\mathbf{s}}{\mathbf{z}}\end{array}$ & $\underset{\substack{\frac{\alpha}{\alpha} \\
\frac{z}{z}}}{z}$ & $\begin{array}{l}\text { 岁 } \\
. \underline{\underline{\underline{u}}}\end{array}$ & 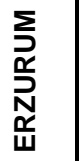 & $\begin{array}{l}\bar{x} \\
\frac{\alpha}{s} \\
\frac{x}{x} \\
\text { I }\end{array}$ & 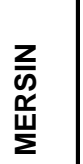 & $\stackrel{\underline{\underline{N}}}{\underline{\underline{N}}}$ & 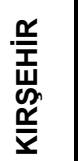 & 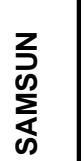 & 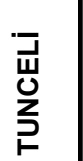 \\
\hline ADANA & 1 & 966 & 612 & 490 & 1046 & 1168 & 809 & 899 & 69 & 901 & 375 & 729 & 622 \\
\hline AĞRI & 966 & 1 & 734 & 1057 & 391 & 1634 & 183 & 434 & 1035 & 1636 & 945 & 754 & 423 \\
\hline AMASYA & 612 & 734 & 1 & 336 & 708 & 900 & 553 & 1145 & 639 & 915 & 308 & 131 & 495 \\
\hline ANKARA & 490 & 1057 & 336 & 1 & 999 & 682 & 115 & 1366 & 483 & 579 & 186 & 419 & 818 \\
\hline ARTVIN & 1046 & 391 & 708 & 999 & 1 & 1546 & 237 & 770 & 1115 & 1578 & 966 & 580 & 461 \\
\hline EDIRNE & 1168 & 1634 & 900 & 682 & 1546 & 1 & 1453 & 2045 & 1161 & 534 & 868 & 966 & 1395 \\
\hline ERZURUM & 809 & 183 & 553 & 876 & 237 & 1453 & 1 & 617 & 878 & 1455 & 764 & 573 & 242 \\
\hline HAKKARI & 899 & 434 & 1145 & 1366 & 770 & 2045 & 617 & 1 & 968 & 1800 & 1180 & 1188 & 650 \\
\hline MERSIN & 69 & 1035 & 639 & 483 & 1115 & 1161 & 878 & 968 & 1 & 893 & 368 & 743 & 691 \\
\hline IZMIR & 901 & 1636 & 915 & 579 & 1578 & 534 & 1455 & 1800 & 75 & 1 & 754 & 120 & 1397 \\
\hline KIRŞEHIR & 375 & 945 & 308 & 186 & 966 & 868 & 764 & 1180 & 368 & 754 & 1 & 391 & 706 \\
\hline SAMSUN & 729 & 754 & 131 & 419 & 580 & 966 & 573 & 1188 & 743 & 998 & 391 & 1 & 575 \\
\hline TUNCELİ & 622 & 423 & 495 & 818 & 461 & 1395 & 242 & 650 & 691 & 1397 & 706 & 575 & 1 \\
\hline
\end{tabular}

Source: Republic of Turkey Ministry of Transportation

- Coverage distance is $500 \mathrm{~km}$ driving distance

- Coverage matrix is as below.

Table 3: Coverage Matrix

\begin{tabular}{|c|c|c|c|c|c|c|c|c|c|c|c|c|c|}
\hline CITY NAME & 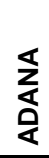 & $\begin{array}{l}\bar{x} \\
\mathbb{0}\end{array}$ & 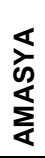 & 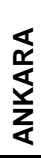 & $\sum_{\frac{\alpha}{\alpha}}^{z}$ & 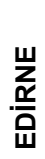 & 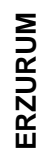 & $\begin{array}{l}\bar{\alpha} \\
\frac{\alpha}{\alpha} \\
\frac{\alpha}{x}\end{array}$ & 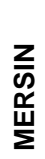 & $\underset{\underline{N}}{\underline{\underline{N}}}$ & 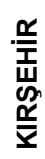 & 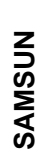 & $\begin{array}{l}\bar{Z} \\
\underline{u} \\
\text { ż }\end{array}$ \\
\hline ADANA & 1 & 0 & 0 & 1 & 0 & 0 & 0 & 0 & 1 & 0 & 1 & 0 & 0 \\
\hline AĞRI & 0 & 1 & 0 & 0 & 1 & 0 & 1 & 1 & 0 & 0 & 0 & 0 & 1 \\
\hline AMASYA & 0 & 0 & 1 & 1 & 0 & 0 & 0 & 0 & 0 & 0 & 1 & 1 & 1 \\
\hline ANKARA & 1 & 0 & 1 & 1 & 0 & 0 & 1 & 0 & 1 & 0 & 1 & 1 & 0 \\
\hline ARTVIN & 0 & 1 & 0 & 0 & 1 & 0 & 1 & 0 & 0 & 0 & 0 & 0 & 1 \\
\hline $\begin{array}{l}\text { EDIRNE } \\
\end{array}$ & 0 & 0 & 0 & 0 & 0 & 1 & 0 & 0 & 0 & 0 & 0 & 0 & 0 \\
\hline ERZURUM & 0 & 1 & 0 & 0 & 1 & 0 & 1 & 0 & 0 & 0 & 0 & 0 & 1 \\
\hline HAKKARI & 0 & 1 & 0 & 0 & 0 & 0 & 0 & 1 & 0 & 0 & 0 & 0 & 0 \\
\hline MERSIN & 1 & 0 & 0 & 1 & 0 & 0 & 0 & 0 & 1 & 0 & 1 & 0 & 0 \\
\hline IZMiR & 0 & 0 & 0 & 0 & 0 & 0 & 0 & 0 & 1 & 1 & 0 & 1 & 0 \\
\hline KIRŞEHIR & 1 & 0 & 1 & 1 & 0 & 0 & 0 & 0 & 1 & 0 & 1 & 1 & 0 \\
\hline SAMSUN & 0 & 0 & 1 & 1 & 0 & 0 & 0 & 0 & 0 & 0 & 1 & 1 & 0 \\
\hline $\begin{array}{l}\text { TUNCELI } \\
\end{array}$ & 0 & 1 & 1 & 0 & 1 & 0 & 1 & 0 & 0 & 0 & 0 & 0 & 1 \\
\hline
\end{tabular}


As seen in the LINDO output of Appendix (Annex 1), if we locate only four locations (x2 (Agri), x3 (Amasya), x6 (Edirne) x9 (Edirne) then our objective value will be 4 and all the demand nodes will be within 500 distance to the at least one of the facility location.

\section{2) Transshipment Problem}

a) Model

The main objective of this project is to minimize the total cost of transportation (shipments from sources to destinations) free coal with respect to fulfilling demand on poor families in demand nodes.

\section{b) List and description of all sets or indexes}

Set $\mathrm{k}=$ transportation methods where $\mathrm{k}=1,2,3$ (highway, railroad, seaway)

Set $i=$ supply nodes where $i=1,2 \ldots, 6(n)$

Set $\mathrm{j}=$ demand nodes where $\mathrm{j}=1,2 \ldots . .8(\mathrm{~m})$

\section{c) Description of all data elements and decision variables}

$\mathrm{X}_{\mathrm{ijk}}=$ number of tons coal transported from node $\mathrm{i}$ to node $\mathrm{j}$ by method $\mathrm{k}$

$\mathrm{C}_{\mathrm{k}}=$ cost of transportation method $\mathrm{k}$ per $\mathrm{km}($ mile $) / \mathrm{ton}$

$\mathrm{D}_{\mathrm{ij}}=$ distance from node $\mathrm{i}$ to node $\mathrm{j}$

$\mathrm{S}_{\mathrm{i}}=$ supply capacity in node $\mathrm{i}$

$\mathrm{P}_{\mathrm{j}}=$ demand in node $\mathrm{j}$

\section{d) Defining the Objective Function}

The objective of the project is to minimize the total cost of transportation for free coal with respect to meeting demand of poor families in demand nodes.

Then objective function for the project is expressed as:

MIN: $\sum_{i=1}^{n} \sum_{j=1}^{m} \sum_{k=1}^{n} D_{i j} X_{i j k} C_{k}$

\section{e) Defining the Constraints}


$\sum_{i=1}^{n} \sum_{j=1}^{m} X_{i j k} \leq \mathrm{S}_{\mathrm{i}} \forall \mathrm{i} \in$

$\sum_{i=1}^{n} \sum_{j=1}^{m} X_{i j k} \geq \mathrm{P}_{\mathrm{j}} \forall \mathrm{j} \in$

$\sum_{i=1}^{n} \sum_{j=1}^{m} X_{i j k}-\sum_{i=1}^{n} \sum_{j=1}^{m} X_{i j k}=0 \forall \mathrm{i} \in \quad$ (Transshipment constraint)

$\mathrm{X}_{\mathrm{ij}}, \mathrm{S}_{\mathrm{i}}, \mathrm{P}_{\mathrm{j}}$ non negativity

\section{f) Implementing the Model}

$\mathrm{MIN}: \sum_{i=1}^{n} \sum_{j=1}^{m} \sum_{k=1}^{n} D_{i j} X_{i j k} C_{k}$

(Supply constraint)

(Demand constraint)

S.T.

$\sum_{i=1}^{n} \sum_{j=1}^{m} X_{i j k} \leq \mathrm{S}_{\mathrm{i}} \forall \mathrm{i} \in$

(Supply constraint)

$\sum_{i=1}^{n} \sum_{j=1}^{m} X_{i j k} \geq \mathrm{P}_{\mathrm{j}} \forall \mathrm{j} \in$

(Demand constraint)

$\sum_{i=1}^{n} \sum_{j=1}^{m} X_{i j k}-\sum_{i=1}^{n} \sum_{j=1}^{m} X_{i j k}=0 \forall \mathrm{i} \in \quad$ (Transshipment constraint)

$\mathrm{X}_{\mathrm{ij}}, \mathrm{S}_{\mathrm{i}}, \mathrm{P}_{\mathrm{j}}$ non negativity

An appropriate way of implementing this model for the project is shown in Excel sheets (Figure 2: Excel Sheet Showing Appropriate way of implementing Model, Figure 3 : Excel Sheet Showing Key Formulas in the Model \& Figure 4 : Excel Sheet Showing Solutions of the Model) of Appendix Section of the study (See Annex 2 for the Excel solution of the Model).

\section{g) Results of the Model}

As seen from the Figure 4 in Appendix section, the minimum total cost (optimal solution) for this problem would be $\mathrm{TC}=\$ 6,723,310$ where all the constraints are meet.

The solutions of the model will also provide us best transportation type and quantity from the related sources to destinations shown in Table 4 below. 
Yönetim ve Ekonomi Araștırmaları Dergisi / Journal of Management and Economics Research

Cilt/Volume: 15 Sayı/Issue: Özel Sayı 1/Special Issue 1 Aralık/December 2017 ss./pp. 40-57

E. Halisçelik Doi: http://dx.doi.org/10.11611/yead.373439

Table 4: Transportation Type and Quantity from Sources to Destinations

\begin{tabular}{|c|c|c|}
\hline $\begin{array}{l}\mathrm{X}_{\mathrm{ij}} \text { will be as } \\
\text { From- to }\end{array}$ & Quantity & Type of Transportation \\
\hline $\mathrm{X}_{\text {Manisa-Edirne: }}$ & 630 ton & Highway \\
\hline X Manisa-Izmir: & 5370 ton & Highway \\
\hline $\mathrm{X}_{\text {Canakkale-Edirne: }}$ & 1150 ton & Highway \\
\hline $\mathrm{X}_{\text {Sirnak-Hakkari: }}$ & 600 ton & Highway \\
\hline $\mathrm{X}_{\text {Corum-Kirsehir: }}$ & 750ton & Highway \\
\hline $\mathrm{X}_{\text {Kutahya-Ankara: }}$ & 3200 ton & Highway \\
\hline $\mathrm{X}_{\text {Bolu-Ankara: }}$ & 850 ton & Highway \\
\hline $\mathrm{X}_{\text {Izmir-Samsun: }}$ & 2590 ton & Seaway \\
\hline $\mathrm{X}_{\text {Izmir-Mersin: }}$ & 2780 ton & Seaway \\
\hline $\mathrm{X}_{\text {Samsun-Amasya: }}$ & 670 ton & Highway \\
\hline $\mathrm{X}_{\text {Samsun-Tunceli: }}$ & 1920 ton & Highway \\
\hline $\mathrm{X}_{\text {Mersin-Adana: }}$ & 570 ton & Highway \\
\hline $\mathrm{X}_{\text {Mersin-Hakkari: }}$ & 810 ton & Highway \\
\hline $\mathrm{X}_{\text {Mersin-Kirsehir: }}$ & 1400 ton & Highway \\
\hline $\mathrm{X}_{\text {Ankara-Erzurum: }}$ & 4050 ton & Railway \\
\hline $\mathrm{X}_{\text {Erzurum-Artvin: }}$ & 1040 ton & Highway \\
\hline $\mathrm{X}_{\text {Erzurum-Tunceli: }}$ & 600 ton & Highway \\
\hline $\mathrm{X}_{\text {Erzurum-Agri: }}$ & 2410 ton & Highway \\
\hline
\end{tabular}

\section{h) Sensitivity Analysis of the Model}

According to Sensitivity Analysis of the Model (Frontline Systems, 2006), we will have the following results by changing either "Right Hand Side Values" or "Objective Function Coefficient" (See Annex 3 for the Sensitivity Analysis of the Model):

Changing Right Hand Side Values: After solving an LP problem, it should be determined how much better or worse the solution would be if we have more or less resources for the project. As seen from the Lindo Sensitivity Output, the shadow (dual) price of the constraints indicates the amount by which the objective function value changes given a unit increase in the right hand side (RHS) value of the constraint, assuming all other coefficients remain constant (ceteris paribus). If a shadow price is positive that means unit increase in the RHS value of the associated constraint results in increase in the optimal objective function of the value. For example as shadow price of Amasya is 167, therefore, if the amount of coal delivered to Amasya changes between the allowable increase and decrease limit 
Yönetim ve Ekonomi Araștırmaları Dergisi / Journal of Management and Economics Research

Cilt/Volume: 15 Sayı/Issue: Özel Sayı 1/Special Issue 1 Aralık/December 2017 ss./pp. 40-57

E. Halisçelik Doi: http://dx.doi.org/10.11611/yead.373439

which are 0 and 670 respectively, our objective function values change by $\$ 167$ for each additional unit. Also note that some variables that have non-binding constraints have 0 shadow price.

Changing Objective Function Coefficient: If the one of the coefficient of the variable change in an allowable decrease or increase limit, the optimal solution of the objective function will not change. For example, if $\mathrm{X}_{111}$ (from Manisa to Edirne) change between allowable increase (167) and decrease (365), the optimal solution of the objective function will not change.

\section{CONCLUSIONS AND POLICY RECOMENDATIONS}

Turkish government delivers free coal to poor families via General Directorate of Coal Industry (GDCI) as a part of social and economic policy. Although project has many components, generally the coal is taken from several mines within country, after basic industrial process, the coal is sent to main delivery nodes from mines nodes by highways, seaways or railroads. Finally, the poor families come to main nodes and carry the coal to their houses to use during the winter.

The cost of delivering free coal is reimbursed by Turkish Treasury to GDCI as duty loss under some government regulations. After giving general information about the problem and describing situation in Turkey, transportation and transshipment models were developed by taking into consideration some assumptions. One of the fundamental objectives should also be closing the gap of life quality between poor and rich people and reducing child sickness because of cold weather.

The project should also aim 3E's (Economy, Efficiency and Effectiveness). In other words, to decrease the cost of delivering coal via shortest path, to produce coal in timely fashion and using best transportation method for the project of "Delivering Free Coal to Poor Families". The problem was solved with alternative methods by giving also following useful and applicable recommendations for GDCI to reduce cost of this public policy and to enable them to help as many as poor families to have free coal in timely fashion:

- Our model shows better solution for current operation,

- The model can be applied to current operations with real distance data among all nodes,

- For full implementation of model given assumptions should be eliminated in timely fashion,

- Management should provide professional consultant service to implement other operations research tools and techniques. 
Yönetim ve Ekonomi Araștırmaları Dergisi / Journal of Management and Economics Research

Cilt/Volume: 15 Sayı/Issue: Özel Sayı 1/Special Issue 1 Aralık/December 2017 ss./pp. 40-57

E. Halisçelik Doi: http://dx.doi.org/10.11611/yead.373439

\section{REFERENCES}

Albright, S.C. (2001), “VBA for Modelers: Developing Decision Support Systems with Microsoft Excel", Pacific Grove, CA: Duxbury-Thompson Learning

Cohon, J.L, (1978), “Multiobjective Programming and Planning”, New York: Academic Press.

Daskin, M.S. (1995), "Network and Discrete Location: Models, Algorithms and Applications", New York: Wiley-Interscience.

Fourer, R., Gay, D.M. and B.W. Kernighan, (2003), “AMPL: A Modeling Language for Mathematical Programming”, Second Edition. Pacific Grove, CA: Thompson-Brooks/Cole

Frontline Systems, (2006), “Frontline Systems Inc.: Developers of Your Spreadsheet's Solver”, [fee-based and free software downloads], http://www.solver.com/.

Hillier, F.S. and G.J. Lieberman, (1995), “Introduction to Operations Research”, Sixth Edition. New York: McGraw-Hill.

GDCI (Türkiye Kömür İşletmeleri Genel Müdürlüğü), (2006), “Bigi/Kömür/Yayınlar”/ http://www.tki.gov.tr/bilgi/komur/73, [Retrieved: December 3, 2006].

Greenberg, H.J. (2006), "Mathematical Programming Glossary”, http://glossary.computing.society.informs.org/.

Johnson, Michael, (2006), “Lectures Notes for 90-772 Operations Research for the Public Sector Class”, H. Carnegie Mellon University John Heinz III School of Public Policy and Management, Fall 2006.

Ragsdale, Cliff, (2004), "Spreadsheet Modeling and Decision Analysis: A Practical Introduction to Management Science”, $4^{\text {th }}$ edition, Thomson Southwestern Publication

Republic of Turkey Ministry of Energy and Natural Resources, (2006), "Info Bank, Energy, Coal", http://www.enerji.gov.tr/en-US/Pages/Coal , [Retrieved: December 10, 2006].

Republic of Turkey Ministry of Transportation, (2006), “Faaliyetler, Istatistikler", http://www.ubak.gov.tr/, [Retrieved: December 8, 2006].

Taha, H.A. (2003), “Operations Research: An Introduction”, 7th Edition. Upper Saddle River, NJ: Prentice-Hall

Winston, W.L. and M. Venkataraman, (2003), "Introduction to Mathematical Programming. Operations Research: Volume One”, Fourth Edition. Pacific Grove, CA: ThompsonBrooks/Cole 
Yönetim ve Ekonomi Araștırmaları Dergisi / Journal of Management and Economics Research Cilt/Volume: 15 Sayı/Issue: Özel Sayı 1/Special Issue 1 Aralık/December 2017 ss./pp. 40-57 E. Halisçelik Doi: http://dx.doi.org/10.11611/yead.373439

\section{APPENDIX}

\section{Annex 1: Lindo Solution of the Model/1}

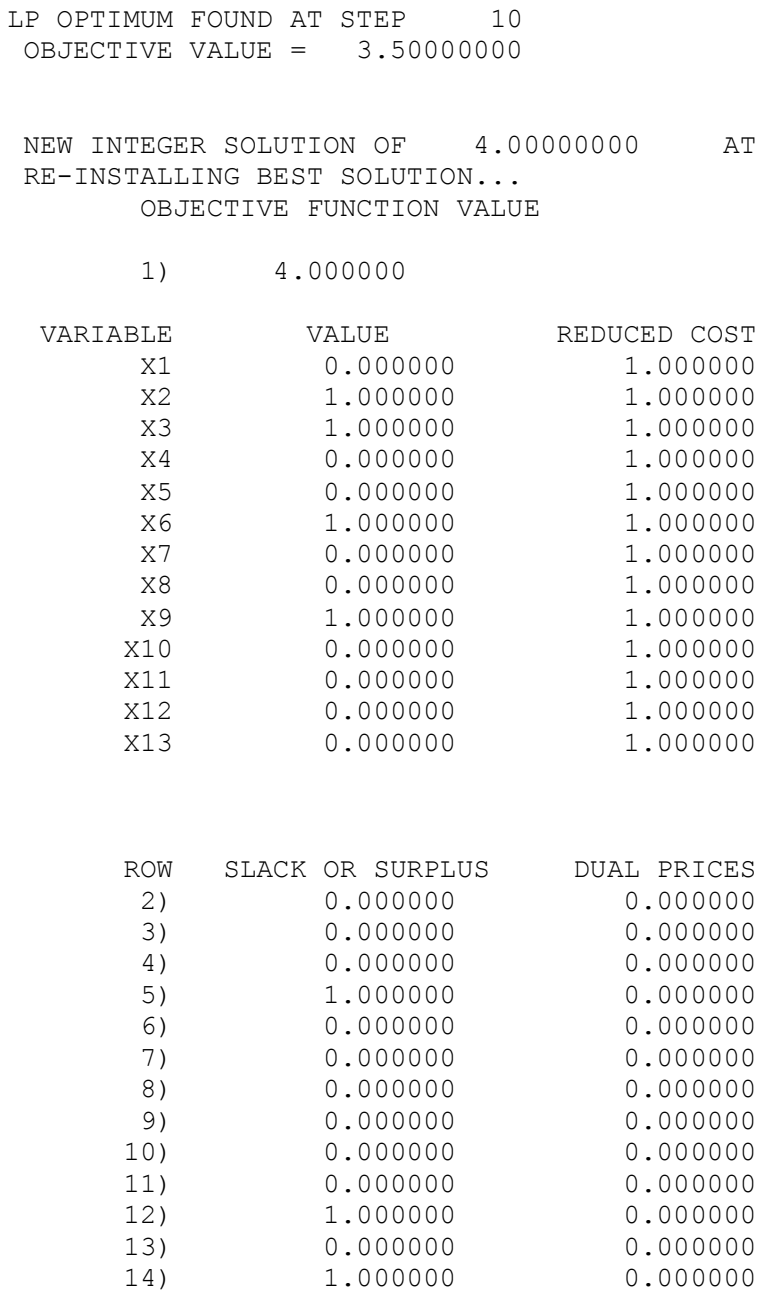

NO. ITERATIONS $=$

10

BRANCHES $=0$ DETERM.$=1.000 \mathrm{E}$ 
Yönetim ve Ekonomi Araștırmaları Dergisi / Journal of Management and Economics Research

Cilt/Volume: 15 Sayı/Issue: Özel Sayı 1/Special Issue 1 Aralık/December 2017 ss./pp. 40-57

E. Halisçelik Doi: http://dx.doi.org/10.11611/yead.373439

\section{Annex 2: Excel Solution of the Model}

Figure 2 : Excel Sheet Showing Appropriate Way of Implementing Model

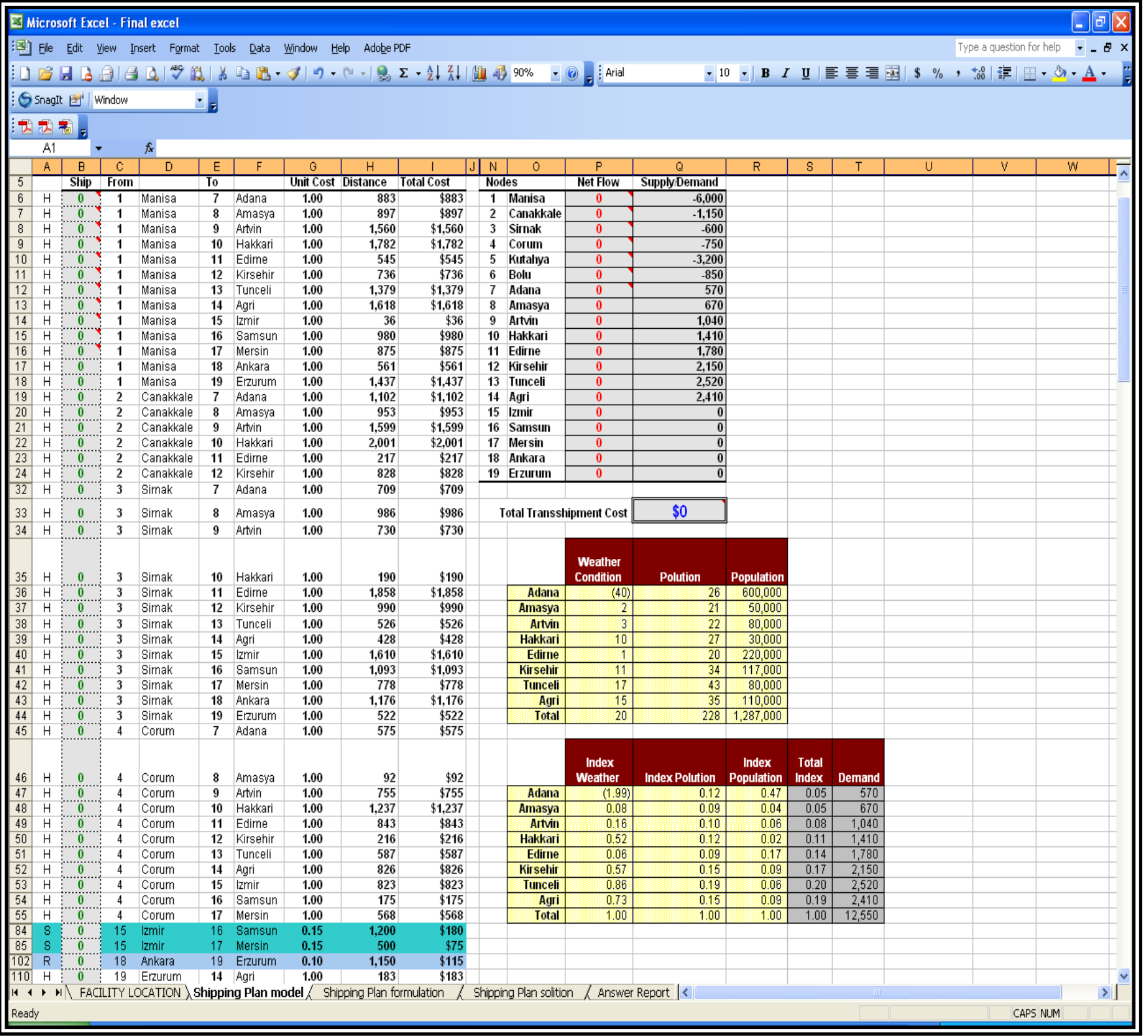


Yönetim ve Ekonomi Araștırmaları Dergisi / Journal of Management and Economics Research

Cilt/Volume: 15 Sayı/Issue: Özel Sayı 1/Special Issue 1 Aralık/December 2017 ss./pp. 40-57

E. Halisçelik Doi: http://dx.doi.org/10.11611/yead.373439

Figure 3 : Excel Sheet Showing Key Formulas in the Model

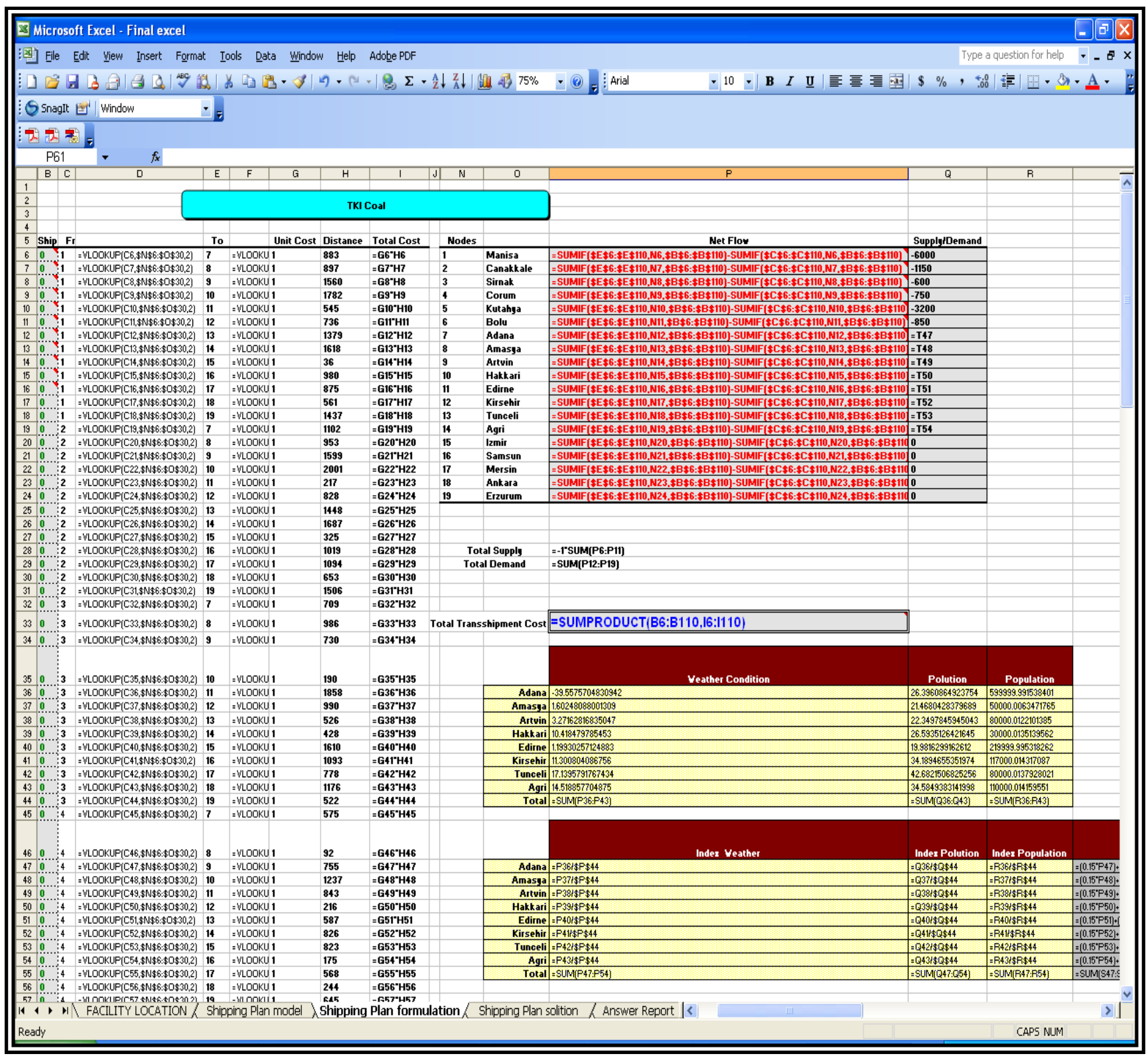


Yönetim ve Ekonomi Araștırmaları Dergisi / Journal of Management and Economics Research

Cilt/Volume: 15 Sayı/Issue: Özel Sayı 1/Special Issue 1 Aralık/December 2017 ss./pp. 40-57

E. Halisçelik Doi: http://dx.doi.org/10.11611/yead.373439

Figure 4 : Excel Sheet Showing Solutions of the Model

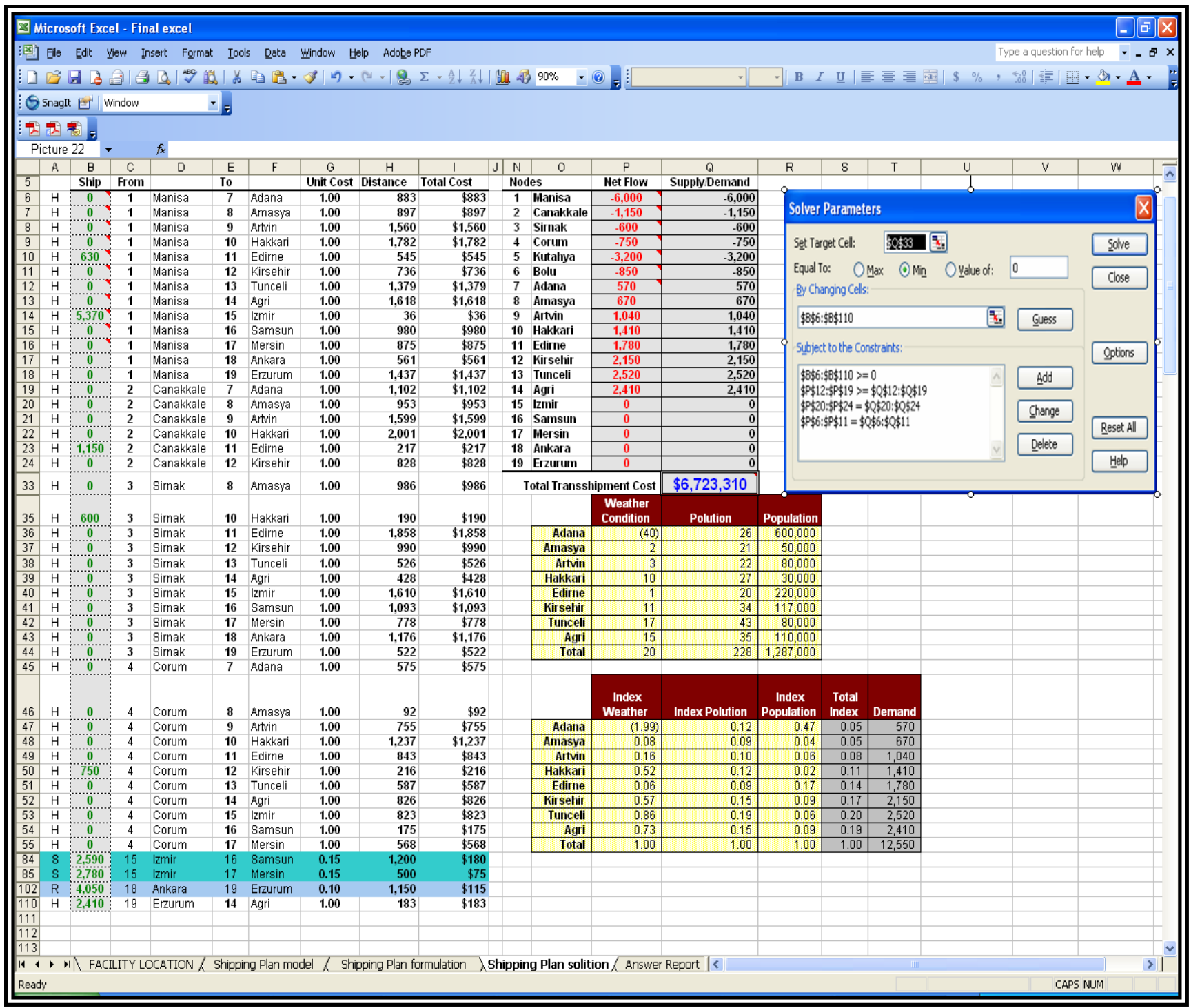


Yönetim ve Ekonomi Araștırmaları Dergisi / Journal of Management and Economics Research Cilt/Nolume: 15 Sayı/Issue: Özel Sayı 1/Special Issue 1 Aralık/December 2017 ss./pp. 40-57 E. Halisçelik Doi: http://dx.doi.org/10.11611/yead.373439

\section{Annex 3: Sensitivity Analysis of the Model}

RANGES IN WHICH THE BASIS IS UNCHANGED:

\begin{tabular}{|c|c|c|c|}
\hline & & OBJ COEFFICIENT & RANGES \\
\hline VARIABLE & CURRENT & ALLOWABLE & ALLOWABLE \\
\hline & $\mathrm{COEF}$ & INCREASE & DECREASE \\
\hline $\mathrm{X} 17$ & 883.000000 & INFINITY & 703.000000 \\
\hline $\mathrm{X} 18$ & 897.000000 & INFINITY & 550.000000 \\
\hline X19 & 1560.000000 & INEINITY & 774.000000 \\
\hline $\mathrm{X} 110$ & 1782.000000 & INFINITY & 703.000000 \\
\hline $\mathrm{X} 111$ & 545.000000 & 167.000000 & 365.000000 \\
\hline $\mathrm{X} 112$ & 736.000000 & INFINITY & 257.000000 \\
\hline $\mathrm{X} 113$ & 1379.000000 & INFINITY & 588.000000 \\
\hline $\mathrm{X} 114$ & 1618.000000 & INFINITY & 886.000000 \\
\hline $\mathrm{X} 115$ & 36.000000 & 127.000000 & 167.000000 \\
\hline $\mathrm{X} 116$ & 980.000000 & INFINITY & 764.000000 \\
\hline $\mathrm{X} 117$ & 875.000000 & INFINITY & 764.000000 \\
\hline $\mathrm{X} 118$ & 561.000000 & INEINITY & 127.000000 \\
\hline X119 & 1437.000000 & INEINITY & 1257.000000 \\
\hline$\times 27$ & 1102.000000 & INFINITY & 1250.000000 \\
\hline $\mathrm{X} 28$ & 953.000000 & INFINITY & 934.000000 \\
\hline X29 & 1599.000000 & INEINITY & 1141.000000 \\
\hline $\mathrm{X} 210$ & 2001.000000 & INFINITY & 1250.000000 \\
\hline X211 & 217.000000 & 547.000000 & INFINITY \\
\hline$\times 212$ & 828.000000 & INFINITY & 677.000000 \\
\hline X213 & 1488.000000 & INFINITY & 1025.000000 \\
\hline X214 & 1687.000000 & INFINITY & 1283.000000 \\
\hline$\times 215$ & 325.000000 & INEINITY & 617.000000 \\
\hline X216 & 1019.000000 & INFINITY & 1131.000000 \\
\hline$\times 217$ & 1094.000000 & INFINITY & 1311.000000 \\
\hline X218 & 653.000000 & INEINITY & 547.000000 \\
\hline X219 & 1506.000000 & INFINITY & 1654.000000 \\
\hline$\times 37$ & 709.000000 & INFINITY & 1418.000000 \\
\hline X38 & 986.000000 & INFINITY & 1528.000000 \\
\hline X39 & 730.000000 & INFINITY & 833.000000 \\
\hline$\times 310$ & 190.000000 & 585.000000 & INFINITY \\
\hline X311 & 1858.000000 & INFINITY & 2202.000000 \\
\hline$\times 312$ & 990.000000 & INFINITY & 1400.000000 \\
\hline X313 & 526.000000 & INFINITY & 624.000000 \\
\hline X314 & 428.000000 & INFINITY & 585.000000 \\
\hline$\times 315$ & 1610.000000 & INFINITY & 2463.000000 \\
\hline X316 & 1093.000000 & INFINITY & 1766.000000 \\
\hline$\times 317$ & 778.000000 & INFINITY & 1556.000000 \\
\hline X318 & 1176.000000 & INFINITY & 1631.000000 \\
\hline X319 & 522.000000 & INFINITY & 1231.000000 \\
\hline$\times 47$ & 575.000000 & INFINITY & 658.000000 \\
\hline$x 48$ & 92.000000 & INFINITY & 8.000000 \\
\hline X49 & 755.000000 & INFINITY & 232.000000 \\
\hline $\mathrm{X} 410$ & 1237.000000 & INFINITY & 421.000000 \\
\hline X411 & 843.000000 & INFINITY & 561.000000 \\
\hline $\mathrm{X} 412$ & 216.000000 & 8.000000 & INFINITY \\
\hline $\mathrm{X} 413$ & 587.000000 & INFINITY & 59.000000 \\
\hline X414 & 826.000000 & INFINITY & 357.000000 \\
\hline$\times 415$ & 823.000000 & INFINITY & 1050.000000 \\
\hline $\mathrm{X} 416$ & 175.000000 & INFINITY & 222.000000 \\
\hline $\mathrm{X} 417$ & 568.000000 & INFINITY & 720.000000 \\
\hline X418 & 244.000000 & INFINITY & 73.000000 \\
\hline X419 & 645.000000 & INFINITY & 728.000000 \\
\hline$\times 57$ & 674.000000 & INFINITY & 617.000000 \\
\hline$\times 58$ & 647.000000 & INFINITY & 423.000000 \\
\hline X59 & 1310.000000 & INFINITY & 647.000000 \\
\hline$\times 510$ & 1573.000000 & INFINITY & 617.000000 \\
\hline X511 & 589.000000 & INFINITY & 167.000000 \\
\hline$\times 512$ & 486.000000 & INFINITY & 130.000000 \\
\hline X513 & 1129.000000 & INEINITY & 461.000000 \\
\hline X514 & 1368.000000 & INFINITY & 759.000000 \\
\hline$\times 515$ & 334.000000 & INFINITY & 421.000000 \\
\hline X516 & 730.000000 & INFINITY & 637.000000 \\
\hline$\times 517$ & 666.000000 & INFINITY & 678.000000 \\
\hline X518 & 311.000000 & 130.000000 & INFINITY \\
\hline
\end{tabular}


Yönetim ve Ekonomi Arasstırmaları Dergisi / Journal of Management and Economics Research Cilt/Volume: 15 Sayı/Issue: Özel Sayı 1/Special Issue 1 Aralık/December 2017 ss./pp. 40-57 E. Halisçelik Doi: http://dx.doi.org/10.11611/yead.373439

\begin{tabular}{|c|c|c|c|}
\hline X519 & 1187.000000 & INFINITY & 1130.000000 \\
\hline X67 & 677.000000 & INFINITY & 740.000000 \\
\hline$x 68$ & 409.000000 & INFINITY & 305.000000 \\
\hline X69 & 1055.000000 & INFINITY & 512.000000 \\
\hline$x 610$ & 1554.000000 & INFINITY & 718.000000 \\
\hline X611 & 491.000000 & INFINITY & 189.000000 \\
\hline X612 & 377.000000 & INFINITY & 141.000000 \\
\hline X613 & 904.000000 & INFINITY & 356.000000 \\
\hline X614 & 1143.000000 & INFINITY & 654.000000 \\
\hline X615 & 595.000000 & INFINITY & 802.000000 \\
\hline$x 616$ & 475.000000 & INFINITY & 502.000000 \\
\hline x617 & 670.000000 & INFINITY & 802.000000 \\
\hline X618 & 191.000000 & 141.000000 & INFINIT \\
\hline$\times 619$ & 962.000000 & INFINITY & 1025.00000 \\
\hline X1516 & 180.000000 & 8.000000 & 87.000000 \\
\hline X1517 & 75.000000 & 87.000000 & 8.000000 \\
\hline X167 & 729.000000 & INFINITY & 765.00000 \\
\hline X168 & 131.000000 & 8.000000 & 167.00000 \\
\hline X169 & 580.000000 & INFINITY & 10.000000 \\
\hline X1610 & 1188.000000 & INFINITY & 325.000000 \\
\hline X1611 & 966.000000 & INFINITY & 637.000000 \\
\hline X1612 & 391.000000 & INFINITY & 128.00000 \\
\hline X1613 & 575.000000 & 10.000000 & 87.00000 \\
\hline X1614 & 754.000000 & INEINITY & 238.000000 \\
\hline $\mathrm{X} 177$ & 69.000000 & 167.000000 & INFINITY \\
\hline $\mathrm{X} 178$ & 639.000000 & INFINITY & 403.00000 \\
\hline $\mathrm{x} 179$ & 1115.000000 & INFINITY & 440.00000 \\
\hline X1710 & 968.000000 & 87.000000 & 585.000000 \\
\hline X1711 & 1161.000000 & INFINITY & 727.00000 \\
\hline X1712 & 368.000000 & 128.000000 & 8.00000 \\
\hline X1713 & 691.000000 & INFINITY & 11.00000 \\
\hline X1714 & 1035.000000 & INFINITY & 414.00000 \\
\hline X1819 & 115.000000 & 130.000000 & 73.00000 \\
\hline X197 & 809.000000 & INFINITY & 1178.00000 \\
\hline X198 & 553.000000 & INEINITY & 755.00000 \\
\hline X199 & 237.000000 & 10.000000 & 606.00000 \\
\hline X1910 & 617.000000 & INFINITY & 87.00000 \\
\hline X1911 & 1453.000000 & INEINITY & 1457.00000 \\
\hline X1912 & 764.000000 & INEINITY & 834.00000 \\
\hline X1913 & 242.000000 & 87.000000 & 10.00000 \\
\hline \multirow[t]{2}{*}{ X1914 } & 183.000000 & 238.000000 & 552.000000 \\
\hline & \multicolumn{3}{|c|}{ RIGHTHAND SIDE RANGES } \\
\hline \multirow[t]{2}{*}{ ROW } & CURRENT & ALLOWABLE & ALLOWABI \\
\hline & RHS & INCREASE & DECREASE \\
\hline 2 & 6000.000000 & INFINITY & 0.00000 \\
\hline 3 & 1150.000000 & 630.000000 & 0.00000 \\
\hline 4 & 600.000000 & 810.000000 & 0.00000 \\
\hline 5 & 750.000000 & 1400.000000 & 0.00000 \\
\hline 6 & 3200.000000 & 1920.000000 & 0.00000 \\
\hline 7 & 850.000000 & 1920.000000 & 0.00000 \\
\hline 8 & 0.000000 & 0.000000 & INFINI7 \\
\hline 9 & 0.000000 & 0.000000 & 2590.00000 \\
\hline 10 & 0.000000 & 0.000000 & INFINIT \\
\hline 11 & 0.000000 & 0.000000 & 1920.00000 \\
\hline 12 & 0.000000 & 0.000000 & 1920.00000 \\
\hline 13 & 570.000000 & 0.000000 & INFINIT \\
\hline 14 & 670.000000 & 0.000000 & 670.00000 \\
\hline 15 & 1040.000000 & 0.000000 & 1040.00000 \\
\hline 16 & 1410.000000 & 0.000000 & 810.00000 \\
\hline 17 & 1780.000000 & 0.000000 & 630.00000 \\
\hline 18 & 2150.000000 & 0.000000 & 1400.00000 \\
\hline 19 & 2520.000000 & 0.000000 & 1920.000000 \\
\hline 20 & 2410.000000 & 0.000000 & 1920.00000 \\
\hline
\end{tabular}

